\title{
Tempo przemian językowych wśród ludności Ciechanowca na Podlasiu
}

Słow a klucze: Ciechanowiec, północno-wschodnia polszczyzna, polszczyzna XVIII wieku, ks. Krzysztof Kluk

Niewielkie miasteczko Ciechanowiec leży na pograniczu Mazowsza i Podlasia w ziemi drohickiej (przed zawarciem Unii Lubelskiej w 1569 r. znajdowało się na obszarze Wielkiego Księstwa Litewskiego). Jest jednym z pięciu najstarszych miast Podlasia. Rzeka Nurzec dzieli je na część lewobrzeżną, starszą - Stary Ciechanowiec i prawobrzeżną, w literaturze określaną jako Nowy Ciechanowiec lub Nowe Miasto Ciechanowiec. Podzieliła je granica na Nurcu pomiędzy Księstwem Warszawskim (później Królestwem Polskim) i Cesarstwem Rosyjskim (na mocy traktatu w Tylży z 9 lipca 1807 r.). Stąd funkcjonująca do dziś nazwa Polska Strona i sporadycznie używana z nacechowaniem negatywnym - Ruska Strona. Utrwalonym efektem owego podziału jest przynależność Ciechanowca do dwóch diecezji. Część lewobrzeżna, z istniejącą od 1446 r. parafią rzymskokatolicką Przenajświętszej Trójcy, znajduje się w granicach diecezji drohiczyńskiej, prawobrzeżna w diecezji łomżyńskiej, z parafią erygowaną w 1998 r. Wcześniej mieszkańcy tej części miasta należeli do parafii z kościołem we wsi Kuczyn oddalonej o 3 kilometry od Ciechanowca (na mocy ukazu cara Aleksandra II w marcu 1870 r. prawobrzeżny Ciechanowiec utracił prawa miejskie i został przypisa- 
ny do gminy Klukowo jako osada Ciechanowiec). Dopiero w 1938 roku obie części zostały połączone w jeden organizm miejski i do dziś stanowią administracyjnie i społecznie całość.

Ciechanowiec ma około pięciu tysięcy mieszkańców o dość jednorodnym składzie narodowościowym i wyznaniowym - są to Polacy wyznania rzymskokatolickiego. W dwudziestoleciu międzywojennym spośród dziesięciu tysięcy mieszkańców miasta połowę stanowili Żydzi. Kahał żydowski powstał w Ciechanowcu w drugiej połowie XVII w. Przed II wojną światową były dwie synagogi, jedna z nich, zbudowana w końcu XIX w., zachowała się do dziś. Osadnictwo ludności wschodniosłowiańskiej do Ciechanowca raczej nie dotarło. W XVIII wieku istniała niewielka parafia unicka z cerkwią pod wezwaniem Świętego Jerzego Męczennika, została zamknięta przez władze carskie w 1832. Cerkiew prawosławną, która stoi do dziś, wybudowano w 1875 roku (por. N. D. Tomaszewski 2012).

Obecnie w Ciechanowcu są następujące szkoły: Szkoła Podstawowa im. Mikołaja Kopernika, Gimnazjum im. Papieża Jana Pawła II i skupione w Zespole Szkół Ogólnokształcących i Zawodowych im. Jarosława Iwaszkiewicza Ogólnokształcąca Szkoła Sztuk Pięknych - Liceum Ogólnokształcące, Technikum, Zasadnicza Szkoła Zawodowa, Uzupełniające Liceum Ogólnokształcące dla Dorosłych, Szkoła Policealna dla Dorosłych.

W mieście jest kilka zakładów przemysłowych z branży spożywczej. Głównym źródłem utrzymania ludności jest obecnie rolnictwo i handel.

W Ciechanowcu urodziłam się, stąd pochodzili moi przodkowie. Choć na stałe w Ciechanowcu mieszkałam tylko we wczesnym dzieciństwie, jestem związana ze społecznością lokalną i wydawało mi się, że mam dobrą orientację w sytuacji miasteczka i wśród jej mieszkańców. Przez całe dorosłe życie świadomie obserwuję przemiany w zakresie regionalnej polszczyzny, jaką posługuje się miejscowa ludność.

Pod względem językowym Ciechanowiec i okoliczne wsie należą do obszaru dialektu mazowieckiego z wieloma cechami charakterystycznymi dla gwar północnej części Podlasia, szerzej - północno-wschodniej Polski.

Gwarowe cechy żywego języka ciechanowiecczan i ludności z okolicznych wiosek zapisywałam od lat 60 . ubiegłego wieku' ${ }^{1}$, tj. od czasu, gdy za-

1 Są to nagrania magnetofonowe dłuższych opowiadań, odpowiedzi na pytania, wyrazy, powiedzenia zasłyszane od przypadkowych osób na ulicy, w sklepie, na targu itd. 
uważyłam, że w mowie mieszkańców Ciechanowca dość szybko następują zmiany. Wychodzą z użycia cechy lokalne na rzecz ogólnopolskich. Pisałam drobne przyczynki na ten temat ${ }^{2}$, zakładając, że kiedyś opracuję słownik języka tej miejscowości. Istotnie, w 2011 roku Łomżyńskie Towarzystwo Naukowe im. Wagów wydało mego autorstwa niewielką pracę pt. Stownik dawnej mowy mieszkańców Ciechanowca i okolicznych wsi na Podlasiu (I. Maryniakowa 2011). W maju bieżącego roku w Ciechanowcu odbyły się promocje tego Słownika, m.in. w miejscowym gimnazjum. Jakież było moje zdumienie, kiedy okazało się, że młodzież gimnazjalna nie zna już, nie tylko nazw przedmiotów, które wyszły z użycia, np. części konnego wozu, fragmentów drewnianych domów - drewniane domy nadal są, ale się ich już nie buduje i pewnie dlatego zanikły nazwy poszczególnych jego elementów. Nastolatki nie znają jednak nawet dawnych nazw wielu desygnatów pozostających w domach, w gospodarstwie, w otoczeniu. Przybrały one nazwy ogólnopolskie, np.:

- parsk - charakterystyczne dla tego terenu piwnice istnieją dotychczas obok wielu wiejskich domów i przy niektórych na obrzeżu Ciechanowca, ale nazwa parsk jest dzieciom zupełnie obca, to się dziś nazywa piwnica;

- kruczek - nazywa się dziś pogrzebacz;

- kosior - 'narzędzie do wygarniania węgli z pieca chlebowego'. Nie mówię już o zapisanych niegdyś przeze mnie starszych nazwach - ożok, pociasek - przedmiot znają, ale nie nazywają, fakt, że istniejące jeszcze w starych domach piece chlebowe bywają używane rzadko, raczej do suszenia owoców lub grzybów, nie do pieczenia chleba.

Znany jest jeszcze wyraz $d y m n i k$, ale powszechnie bywa zastępowany przez wieloznaczny wyraz komin.

Zaskoczyło mnie to, zaczęłam pytać dorosłych - rodziców tych dzieci okazało się, że znajomość dawnej leksyki obecnie jest niewielka. Wyrazy, które były używane jeszcze 30, 40 lat temu, dziś są po prostu zapomniane.

Byłam zdumiona, że w bardzo krótkim czasie, dziesięciu - dwudziestu lat nastąpiły takie zmiany w mowie i w świadomości miejscowych ludzi. Większość mówi obecnie językiem ogólnopolskim o pewnym regionalnym zabarwieniu.

2 I. Maryniakowa 1989: 173-177; 1991: 33-39; 1996: 209-218; 2004: 43-51; 2009: 131-140; 2010: 191-198; 2012: 147-215. 
Dość naturalne wydawało mi się ustępowanie takich cech językowych, jak np.

- mazurzenie. Wyrazista niegdyś cecha fonetyczna, w początkowym okresie zapisywania przeze mnie materiału językowego występowała już rzadko, zwykle w wyrazach, nie będących w powszechnym użyciu, które nabrały cech zleksykalizowania, lub w utartych zwrotach, w przysłowiach. Zapisałam jeszcze, np. cerep 'czerep'; ceszpać 'czerpać'; casowy 'mający wolny czas'; scepać 'szczepać'; sadź 'szadź'; kosałka 'koszałka'; salej obok szalej 'roślina - blekot'; wieza 'wieża'; kuzy gdak; kuze łocka 'roślina - ognicha'; kołace się po głowie 'szukam (mam) w pamięci'; poleciał zadersy ogona 'pobiegł szybko, nie zważając na nic;

- miękka wymowa tylnojęzykowych $k, g$, ch przed samogłoskami przedniego rzędu - kieks 'keks'; kiempa 'kępa'; kieńdzierzawy; chiba; suchi; gluchi; giemba; gieńś 'gess'; mogie; tagieńdzić sie 'łasić się';

- występowanie spółgłoski protetycznej w nagłosie towies; toś 'oś'; na łosi; topleć 'opleć'; łobijać; tosma 'ósma'; łoba 'oba';

- brak pochylenia samogłoski o-prok; gora; loft; rosol; gnoj; rowieźnik 'rówieśnik', także w końcówce dopełniacza liczby mnogiej rodzaju żeńskiego: kurof; myszof; skfarkof; tabletkof; rencof 'rąk';

- zwęż e n i e o > u-dunica; kuń; kuniec; kuńczyć; murg 'morga-miara powierzchni gruntu'; pułowa;

- występowani e $a$ na miejscu $e$-cadzić; cadzitek'szmatkado cedzenia mleka'; jadzie;

- przej ści i ar > er-derta się; siedziat rosperty; pomer; umerta;

- przejście nagłosowe go ra>re-redlić 'pracować radłem'; redzić 'radzić'; seredela 'seradela'.

Tych cech już prawie nie słyszy się. Natomiast, wspomniane powyżej zabarwienie regionalne wynika z utrzymywania się dłużej cech morfologicznych i składniowych należących do warstwy gwarowej języka. Dotychczas w mowie, nie tylko starszego pokolenia, występują takie zjawiska językowe, jak:

- używanie form rzeczowych w miejsce męskoosobow y ch - muzykanty; strażaki; oficery; policjanty; dziatki 'dziadkowie'; ludzie takie mondre;

- używanie końcówek męskoosobowych w trzeciej osobie liczby mnogiej czasu przeszłego przy rzeczownikach i zaimkach wszyst- 
kich rodzajów - lepy takie byli; legary leżeli na takiej polepie; dziewczyny jusz poszli do kościoła;

- forma trzeciej osoby liczby pojedynczej czasowni$\mathrm{k}$ a być - jest - bywa używana zamiast liczby mnogiej $s q$-odpowiedź na pytanie, czy odnalazły się dzieci: oni jest jusz w domu; $w$ Rosji tesz jest prywatne gospodarstwa; czy rogaliki jeszcze jest? (pytanie w sklepie);

- występowanie form analitycznych czasu przeszłego z zaimkiem osobowym w funkcji wykładnika osoby - ja jemu zafsze pomagała w robocie; ty dtugo dziś spała; a ty jusz tam byt?; my nic nie robiem teras; zwrot do dzieci: poszli by wy do bapci;

- szeroka repartycja przyimka dla-jak jusz jestem, to dla pana burmistrza powiem; czy państwo wiecie, że dla księdza zginał bratanek?; dziękuje dla członkóf Towarzystfa za konserwacje pomnika; dla niego często boli głowa; jak ja będe wygladała dla tej pani (wobec pani doktor), co mnie tam zawiozła.

- podwajanie przedrostków - po pociemku 'po ciemku', po podlesiu, po podlasiu 'brzegiem lasu'; po podpłociu 'pod płotami'; pozagumieniu, pozagumniu 'poza gumnami'; pozastodolu 'poza budynkami gospodarczymi'; popomacku 'macając rękami w ciemnościach'; na odwyrtkie 'odwrotnie zrobić coś, na odwrotną stronę założyć'; napowsiaść się na kogo ' uwziąć się na kogoś'; naotsiepkie 'w odwrotną (lewą) stronę'. - utrzymywanie się formacji odprzymiotnikowych z s ufiksem - ovat- - durnowaty; brudnowaty; zielonkowaty, zuchowaty; cieplowato.

W zapisywanych dawniej materiałach z Ciechanowca często były używane takie wyrazy, jak: bachnać 'uderzyć'; brzechać 'szczekać (o psie) i kłamać'; buchnqć 'upaść na ziemię'; schmulić się 'zasępić się'; rozchmulić się 'wypogodzić twarz'; guziołek 'guzek na ciele i węzełek na tkaninie'; siepki 'wystrzępione nitki lub małe skrawki tkaniny po wyrównaniu brzegu'; zuchelatek 'kawałeczek'; musowo 'koniecznie'; na przyboś 'w obuwiu założonym na gołą stopę' i wiele innych, które z rzadka można jeszcze dziś słyszeć. Występują szczególnie w mowie starszych osób.

Proces zachodzących zmian w języku ludności zamieszkującej na terenie Ciechanowca i w jego okolicy można obserwować od połowy XVIII wieku. W dziełach księdza Jana Krzysztofa Kluka - autora książek przyrodniczo-gospodarskich drukowanych w latach 1777-1789 - są liczne przy- 
kłady nazw i form, zachowanych na omawianym terenie prawie do czasów obecnych. Ksiądz Kluk (żył w latach 1739-1796) był ciechanowiecczaninem $\mathrm{z}$ urodzenia i z wyboru. Wszystkie prace pisał, będąc proboszczem w parafii ciechanowieckiej. Teksty drukowane i rękopiśmienne księdza Kluka, pisane językiem literackim, mają i tę wartość, że są źródłem wiadomości o mowie dawnych mieszkańców omawianego tu terenu. W pismach K. Kluka, szczególnie chronologicznie najwcześniejszych ${ }^{3}$, które dotyczą życia i pracy ludności wiejskiej i które były skierowane do wiejskiego odbiorcy, znajduje odbicie ówczesny miejscowy język. Kluk pouczał rolnika, jak ma uprawiać ziemię, co kiedy sadzić, zbierać, jak przechowywać i wykorzystywać płody rolne. W związku z tym pisał tak, aby treść była rozumiana przez szerokiego odbiorcę, niezależnie od wykształcenia i walorów intelektualnych. Używał języka prostego, często w formie kolokwialnej. Z jego tekstów można wyodrębnić leksykę i cechy językowe, które jeszcze w drugiej połowie XX wieku charakteryzowały mowę na terenie Ciechanowca, np.:

- składnia liczebnika - w Ciechanowcu po liczebnikach głównych dwa, trzy, cztery, można usłyszeć rzeczowniki w dopełniaczu czszy godzin czekałam; on ze czszy krof miat - a przy liczebnikach pięć i wyżej w mianowniku - dużo było (ludzi) z dziesięć rzendy ławek dla dzieci; dziesięć litry wody. Podobne przykłady zdarzają się w dziełach Kluka, np. ...gdy ochtodnie poddaie się cztery tyżek drożdży cieptych (Roślin ... T. II 1788, s. 14); gdy tak postoi 24 godzin, wyciska się woda (Roślin ... T. II, 1778, s. 275);

- czasowniki bezprzedrostkowe i ich pochodne na omawianym terenie przed laty zapisywałam dość często: najdować 'znajdować; naleźć

3 Trzy tomy „Roślin potrzebnych, pożytecznych, wygodnych osobliwie kraiowych, albo które w kraiu użyteczne być moga, utrzymanie, rozmnożenie i zażycie”. Tom I. $Z$ Figurami. O drzewach, ziołach ogrodowych, i ogrodach przez X. Krzysztofa Kluka kanonika kruswickiego, proboszcza ciechanowieckiego, w Warszawie w Drukarni Jego Królewskiey Mci i Rzeczypospolitey u XX.: Schol.: Piar.: roku 1777; T. II. Z Figurami. O drzewach, $i$ ziołach dzikich, lasach, et. c. ... Roku 1778; Tom. III Z figurami. O rolnictwie, zbożach, łakach, chmielnikach, winnicach y roślinach gospodarskich ... r. 1779. Materiał przytoczony w dalszej części niniejszego opracowania pochodzi z różnych wydań powyższego opracowania oraz Zwierzat domowych i dzikich, osobliwie krayowych, historyi naturalney poczatki i gospodarstwo. Potrzebnych i pożytecznych domowych chowanie, rozmnażanie, chorób leczenie, dzikich łowienie, oswoienie, zażycie, szkodliwych zaś wygubienie. T. I. z figurami, O zwierzętach ssacych, przez x. Krzysztofa Kluka w Warszawie r. 1779. 
'znaleźć'; dzieś najdziem 'gdzieś znajdziemy'; przedaż 'sprzedaż'; obaczyć 'zobaczyć'; obacz tam 'zobacz', u Kluka podobnie: Drdzeń po większey części nayduie się w pośrzodku drzewa (Roślin ... T. II 1788, s. 8); byleby drzewo na mieysce, na czas do przedaży sposobny przystawiać sobie mogt (Roślin ... T. II 1788, s. 149); obaczy pomnożone pożytki poddany i podobnież sobie czynić będzie (Roślin ... T. III 1823, s. 39); czasem na iedney szyszce wszystkie się razem naleść moga (Roślin ... T. III 1823, s. 152);

- formacje odprzymiotnikowe z sufiksem - ovat- występują u Kluka, podobnie jak ma to miejsce w mowie ciechanowieckiej, np. Kora na dębie siwowata i chropowata iest... (Roślin ... T. II 1788, s. 17). $\mathrm{Z}$ dziedziny leksyki także liczne wyrazy gwarowe w mowie ludności ciechanowieckiej przetrwały od czasów Kluka do nam współczesnych:

- us zak 'umocowana w ścianie rama drzwi lub okna'. Z tekstów Kluka - uszaki drzwiow w budowie (Regestr drzewnych rzeczy, które z iakiego drzewa robione bywaiq zamieszczony w Roślin ... T. II 1778, s. 165). Wyraz dotychczas dość powszechnie używany na Podlasiu.

- osmorgnać, osmorgnięty w moich materiałach jest kilka znaczeń tego wyrazu: 'obetrzeć z wierzchniej warstwy', 'otrzeć skórę z ciała', 'oberwać pociągając ręką w dół' - u Kluka np. osmorgane liście brzozy (Roślin ... T. III 1823, s. 122);

- mulać, obmulać, namulać 'trzeć, ocierać; obetrzeć' obmulata pięta; omulit się koń; także u Kluka w odniesieniu do zwierząt i do człowieka - w iarzmach woly ... przynaymniey na rogach nie mulaiq sie (Zwierząt ... T. I 1795, s. 211); kark ieżeli nie nadmulony ... (Roślin ... III 1823, s. 121);

- miarkować wyraz występuje z różnymi przedrostkami, znaczy 'wyważać, określać'- np. oni wymiarkowali, że lepiej tam nie iść; u Kluka podobnie: co do wielkości gnoiow, pomiarkuie się rolnik z gruntu ... (Roślin ... T. III 1781, s. 108); naylepieyby byto, aby proporcyonalnie wymiarkowawszy, bez obciqżenia wyznaczyć im ... (Roślin... T. III 1823, s. 116); nierozumnie leczy, kto chce uzdrowić od choroby, nie uprzatnqwszy zrzodta iey [...] aby wymiarkować pteć, wiek, sity, natężenie choroby. (Roślin ... T. II 1788, s. 273)

- wyraz s zkodować używany obecnie znaczy 'oszczędzać kogo, żałować' ale w znaczeniu, jakie występuje u Kluka 'ponosić szkodę' notowa- 
łam w latach 70. w okolicy Ciechanowca (Usza Wielka) - u Kluka koń [...] bardzo goracy przy ciężkiey robocie szkodować może: bardzo leniwy, nie przysporzy roboty ... (Roślin ... T. III 1823, s. 122);

- zapomóc się 'zaopatrzyć się, u Kluka często spotykany, np. gdzie skapość lasów niedostatkiem drzewa uciska, podat rękę sposobem innych narodów zapomożenia się w lasy ... (Roślin ... T. II 1788 r., s. 1)

- wyraz nazat 'do tyłu, z powrotem’ w Ciechanowcu słyszy się dość często, u Kluka jest powszechny, np. wilgoć [...] tłoczy się z korzenia w pień, a udzieliwszy się tyle, ile do wzrostu potrzebna iest, powraca nazad do korzenia ... (Roślin ... T. II 1788 r., s. 3)

- sporno 'sprawnie, szybko', np. nie sporno ci to idzie. U Kluka spor, sporność, sporniey, sporzey występuje często w różnych znaczeniach Do przewrocenia i spulchnienia ziemi, zwłaszcza w takiey sporności, iakiey potrzebuie wielkość roli ... (Roślin ... T. III 1823 r., s. 124); O Sporze rośnienia drzew (Roślin ... T. II 1788 r., w spisie treści Rozdział III, 3); gałazki jego sporniey rosna (Roślin ... T. II 1788 r., s. 18); do przewrócenia i spulchnienia ziemi, zwłaszcza w takiey sporności, iakiey potrzebuie wielkość roli (Roślin ... II 1778 r., s. 86, 124).

- gwarowe napodorędziu 'mieć, być pod ręką, tuż obok; na poczekaniu'; wyraz napodorędzić sie można objaśnić potocznym 'nawinąc się' - u Kluka w tym znaczeniu jest zwrot na dorędziu; aby byty na dorędziu (Roślin ... t. III, s. 89).

Leksyka na omawianym terenie jest interesująca ze względu na krzyżowanie się polszczyzny z obszaru mazowieckiego z polszczyzną północno-wschodnią, w tym kresową. Oprócz licznych archaizmów, które dawniej zapisywałam, np. borgować, karaczan 'karaluch', odwieczerz, odzienie, termedja 'kłopot', do dziś w mowie mieszkańców, występują wyrazy z pochodzenia wschodniosłowiańskie - bołtun 'zbuk, jajko z martwym zarodkiem', bożyć się, brzechać, chabor, domówić się 'porozumieć się, kozerek i rzadziej litewskie - błat: po błatu 'po kumotersku, na lewo', bontka 'pierwsza kromka odcięta $\mathrm{z}$ bochenka chleba, mała bułeczka z ciasta drożdżowego, kawałek surowego ciasta zostawiony w dzieży na zakwas', kumpie 'biodro u zwierząt'. Ciągle żywe są wyrazy, występujące w słownikach języka polskiego z kwalifikatorem - ,przestarzałe” lub „pospolite”, np. cacko, chruściki, bachor 'małe dziecko obojga płci' (bachur 'to samo', a 'nieślubne dziecko' to bachurek lub bajstruk) i wiele innych. 
Wiadomo, że w mowie przedstawionej tu niewielkiej społeczności zachodzą zmiany - toczyły się dawniej i przebiegają współcześnie, z tą różnicą, że niegdyś następowały powoli. Do niedawna, starałam się to pokazać, istniały pozostałości sprzed wieków, dziś w ciągu jednego życia następuje kilka etapów eliminowania jednej rzeczywistości i pojawienie się innej, które znajdują przełożenie w języku codziennym - choćby najprostsze przykłady: wieczne pióro - długopis, maszyna do pisania - komputer; telefon na poczcie, budka telefoniczna - telefony komórkowe u każdego w kieszeni, itd. Znaczące przemiany społeczne, które w połowie XX wieku nastąpiły w tej okolicy, podobnie jak w całej Polsce, miały wpływ na egzystencję ludzi. Dostępne stały się w życiu codziennym liczne udogodnienia cywilizacyjne, upowszechniły się środki masowego przekazu - radio, później telewizja, czynniki, które zauważalnie zaczęły przekładać się na przyspieszone i dość radykalne wyzbywanie się dawnego, nacechowanego gwaryzmami sposobu mówienia. Istotne znaczenie dla zmian zachodzących w mowie miała tu edukacja dzieci, szczególnie możliwość kształcenia się w szkołach ponadpodstawowych i wyższych. Dziś większość mieszkańców używa języka ogólnopolskiego z pewnymi cechami regionalnymi, ale wyraźne gwaryzmy, które notowałam w początkowym okresie zbierania materiału, w ich mowie słyszy się znacznie rzadziej.

Na zakończenie należy powiedzieć, że ,dawną mowę” można jeszcze obserwować wśród miejscowej ludności przy pobudzeniu emocjonalnym o różnorakim pochodzeniu, np. przy okazji miłych spotkań, szczególnie we własnym gronie, albo wprost przeciwnie - w sytuacjach konfliktowych wśród sąsiadów, kłótniach, gniewie, obmowie. Ale nie tylko...

Dawniej było określenie koń zaciagu dostał „koń przepracował się do takiego stopnia, że nie może się ruszać. Obecnie konie jako siła pociągowa prawie całkowicie zniknęły. Zanotowałam przenośne użycie tego zwrotu. Skarżył się mężczyzna: jusz nie moge wytrzymać, chyba jak koń dostałem zaciagu. Niedawno, będąc w Ciechanowcu, zapytałam sąsiadkę o zdrowie, odpowiedziała: bajki, może być, czyli 'wszystko w porządku, nic szczególnego mi nie dolega'. Wyraz bajki niegdyś często używany oznacza, że jest nieźle, nic złego się nie dzieje. 


\section{Bibliografia}

Maryniakowa I., 1989, Uwagi o języku pism księdza Krzysztofa Kluka - przyrodnika z Ciechanowca, w: I. Maryniakowa, E. Smułkowa (red.), Studia językowe z Białostocczyzny. Onomastyka i historia języka, Prace Białostockiego Towarzystwa Naukowego, Nr 33, Warszawa: PWN, s. 173-177.

MARYNIAKOWA I., 1991, Zaimek s i ę wykładnikiem nieokreśloności. (Na materiale tekstów Krzysztofa Kluka i współczesnej gwary Ciechanowca oraz najbliższej okolicy), Studia z Filologii Polskiej i Słowiańskiej XXVII, s. 33-39.

Maryniakowa I., 1996, Słowniczek przedmiotów z drewna. (Przyczynek do polszczyzny XVIII wieku), w: E. Rzetelska-Feleszko (red.), Symbolae slawistice, Warszawa: Polska Akademia Nauk, s. 209-218.

Maryniakowa I., 2004, Mikrotoponimia Ciechanowca, w: H. Sędziak (red.), Polszczyzna Mazowsza i Podlasia, część VIII: Antroponimia i toponimia Mazowsza i Podlasia, Łomża: Łomżyńskie Towarzystwo Naukowe im. Wagów, s. 43-51.

Maryniakowa I., 2009, Mowa ludności Ciechanowca i okolicy dawniej i dziś, Ciechanowiecki Rocznik Muzealny 5, z. 2, s. 131-140.

MARYNiAKowa I., 2010, O dziełach Krzysztofa Kluka w świetle badań gwarowych na Podlasiu, Acta Baltico-Slavica 33, s. 191-198.

Maryniakowa I., 2011, Słownik dawnej mowy mieszkańców Ciechanowca i okolicznych wsi na Podlasiu, Łomża: Łomżyńskie Towarzystwo Naukowe im. Wagów.

Maryniakowa I., 2012, Dawna leksyka Ciechanowca i okolicznych wsi, Acta Baltico-Slavica 36, s. 147-215.

Tomaszewski N. D., 2012, Historia Ciechanowca do roku 1989, Ciechanowiec: Libra s.c. Wydawnictwo i Drukarnia PPHU, Urząd Miejski w Ciechanowcu.

\section{The rate of change of language in the population of Ciechanowiec in the Podlasie region}

( s u m m a r y)

Ciechanowiec is one of the oldest cities in the Podlasie region, located in the south - western part of the region. The town is situated in the region of the Masovian dialect, with many features characteristic of the north-eastern Polish dialects. The earlier Polish language, which has preserved vocabulary and grammatical features recorded in the eighteenth-century works of Christopher Kluk (naturalist from Ciechanowiec), is at the turn of the twentieth and twenty-first century rapidly disappearing. It is displaced by the nationwide language, heard on radio and television. 